\title{
Anniversary \\ Professor dr.ing. \\ Gheorghe MARIA \\ at 65 years old - \\ teacher and scientist
}

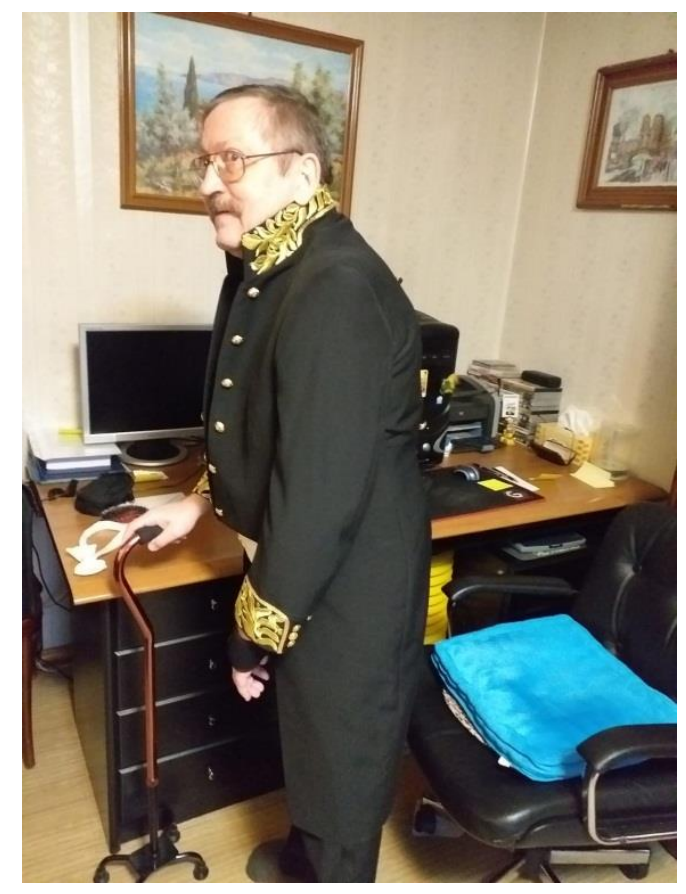

\section{CRISTIANA LUMINITA GIJIU ${ }^{1}$, DANIEL DINCULESCU ${ }^{2 *}$, MARA CRISAN ${ }^{2}$}

${ }^{1}$ University Politehnica of Bucharest, Dept. of Chemical and Biochemical Engineering, Romania

${ }^{2}$ Siemens S.A. Romania

Abstract. Prof. Dr. Ing. Gheorghe Maria from University Politehnica of Bucharest (UPBuc.), Department of Chemical and Biochemical Engineering is a valuable scientist in Romania, being the successor and continuer of the Romanian school of (bio)chemical reactors and reaction engineering, but also the creator of novel courses in the (bio)chemical engineer curricula at UPBuc. His research interests include a wide range of classic but also modern border fields, namely (bio)chemical reactors, kinetic modelling, bioinformatics, chemical reactors risk analysis, modelling dynamics of cell metabolic processes, of gene regulatory circuits, and of controlled drug release. Following the large number of international cooperations (20), its scientific productivity is impressive, including over $\underline{\mathbf{2 3 0}}$ papers in ISI journals and intl. Conferences, $\underline{11}$ ISBN books (RO,USA), $\underline{5}$ teaching books (UPBuc., $R O)$, and $\underline{\mathbf{6}} I S B N$ book chapters abroad. Their practical realizations include the design and putting into operation of an industrial plant in Romania (at Petrochemical works /Refinery Brazi-Ploiesti, Romania, PWBP, 1985), of a lab-scale pilot plant in Switzerland (Paul Scherer Inst., 1992-1998), or a safety-based optimization of a semi-batch (SBR) reactor (at CIBA-Novartis, Basel, 1994-1996). Based on these multiple contributions, it can be stated that Prof. Maria has had a significant impact on the science and the practice of Chemical and Biochemical Reaction Engineering in Romania and worldwide, his publications being well cited (Hirsch index 20, I10 index 49, more than 1400 citations). In 2019 he joined (unanimously by votes) the Romanian Academy. as a correspondent member.

\footnotetext{
*email:danieldinc@yahoo.com; gmaria99m@hotmail.com
} 


\section{Career (Institutions)}

1974-1979. BSc. in Organic Chemistry, and MSc. in Chemical Engineering at UPBuc., Romania.

1979-1982. In-stage Chemical Engineer (Plant engineer) with Organic Chemical Enterprises in Bucharest.

1982-1990. Research Scientist with ICECHIM (Central Institute of Chemistry) - Chemical \& Biochemical Energetics Inst. Bucharest, (Bio)Catalysis Group.

1991-1992. Lecturer (Assistant Professor) with Dept. of Chemical and Biochemical Engineering of UPBuc.

1992-1997. Asistant Profesor with Swiss Federal Institute of Technology - ETH Zürich (Switzerland), Chemical Engineering Department, PSE group of late prof. David W.T. Rippin.

1997-1999. Associate Professor in Chemical \& Biochemical Reactors and Reactions Engineering with UPBuc.

From 1999. Full Professor in Chemical \& Biochemical Reactors and Reactions Engineering with UPBuc.

2002-2003. Senior Research Scientist (NIH fellow) with Texas A\&M University (College Station, Texas, USA), Dept. of Chemistry, Biochemistry, and Cell Biology (2002-2003).

From 2019 he is a correspondent member of the Romanian Academy (Fig. 8)

\section{Education and acclaim (early life)}

Prof. Maria was born in Fundeni (Călăraşi county, RO), a village which is very close to Bucharest, on October 2, 1955, being the middle child of a family with very old and strong roots in Oltenia (via his father) and Muntenia (via his mother). The grandparents on the maternal line, although with many children (6), have been quite wealthy, as his grandfather received a lot of land as a veteran of the battles of Marasesti and Oituz (WW1), as well as when he was decorated in high orders. As the Communist regime disposed of all their goods around 1950-1955, almost all his children had to shape their future by moving to Bucharest.

So it's like, the family of dr. Maria lived exclusively in Bucharest. But, as the family material resources were extremely poor (with a domestic mother), after 1953, his family had to change their rented flat several times, by moving among various districts of Bucharest. Withal, Gigi (nickname of Prof. Maria) kept a close connection with the parent families in their home villages, during the wonderful summer and winter holidays spent there (Fundeni/ Calaraşsi, and Baloteşti/Ilfov).

Over years, during primary school, Gigi received from his father, a border guard colonel, a very strong and strict education, based on seriousness, discipline, organizational skills, accuracy and fairness, also always open to new ideas and with a great love of his country to which he has always been proud to belong. Already in Bucharest during his primary studies, he reported exceptional top results, being an imaginative spirit, extremely curious, and with talent to exact sciences. He often read in advance the textbooks of his two year older brother.

After graduating secondary school, he attended Gh.Lazãr lyceum/highschool (1970-1974), which is one of the top high-schools in Bucharest, in a class specialised on Chemistry and Maths, lead by late prof. Mariana Andrei, who knew how to channel his talent towards a rigorous study of Chemistry [5,35]. During his secondary studies in Bucharest, he reported exceptional top results, being an imaginative spirit, extremely curious, and inventive, particularly attracted to Chemistry and Mathematics.

He quickly became noted for his original math approach to solving many chemical problems. He participated to a large number of high-school national competitions (so-called national Olympiads in Chemistry or Maths), by winning several awards. He was also a fervent supporter of Revista de Fizica si Chimie (Bucharest) for high-school peoples, where he contributed with problems to be solved, and where he published his first paper: Maria,G., Antiferromagnetism of magnetite, Revista de Fizica si Chimie B, 11(1), 6-10 (1974). 
Due to their outstanding results, in 1974, he was included in the Romanian team to participate to the $6^{\text {th }}$ IChO (International Chemistry Olympiad) for highschool peoples (11 participating countries, including Czechoslovakia, Poland, Hungary, Bulgaria, GDR, Romania, Soviet Union, Sweden, Yugoslavia, Austria, BRD)[23a-b]. At this esteemed and traditional contest, G. Maria won the Gold Medal by presenting original and ingenious solutions to several difficult chemical / computational chemistry problems. Being impressed by his success, writer Eugen Seceleanu, dedicated one chapter in his book to him[12].

Due to such an exceptional achievement, in 1974 he was admitted at UPBuc. without any exam, to study chemical engineering (Industrial Chemistry Faculty), where he chose to become BSc in Organic Chemistry, and MSc in Chemical Engineering, specializations to which he was particularly attracted. Later, this attraction will be materialized in a large number of innovative published studies on math modelling the kinetics of catalytic chemical processes, but also proposing kinetic math models of various metabolic (biochemical) processes in living cells. To achieve these ambitious goals, he was starting to study the theory of statistical estimation in depth. Later, during his doctoral studies, such extensive knowledge, allowed him to develop novel numerical algorithms for statistical estimation, and process optimization (for solving NLP, MINLP problems). Starting from these solid theoretical bases, later he reported lots of contributions in the area of multi-objective optimization of industrial chemical, enzymatic reactors, or bioreactors.

During his university studies, he attended the courses of valuable professors, such as Prof. Ecaterina Ciorănescu-Neniţescu, and Prof. Margareta Avram for Organic Chemistry, Chemical reaction engineering with Prof. Raul Mihail, Chemical process optimization with Prof. Octavian Smigelschi, Transport phenomena with Prof. Octavian Floarea, and others. He graduated the UPBuc. in 1979 as valedictorian (Figure1).

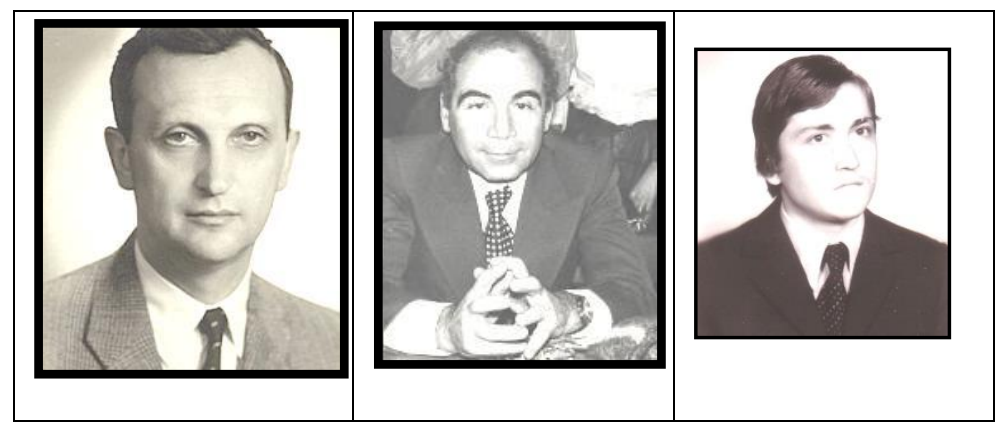

Figure 1. Doctoral advisor late Prof. Raul Mihail. Diss title: Parameter Estimation of the Mathematical Models of (Bio)Chemical Processes (1987).; [center] MSc advisor late Prof. Octavian Smigelschi. Diss title: Modelling and optimization of a multi-cell sugar extractor (1979); [right] G. Maria MSc graduate of UPBuc as valedictorian (1979)

During his college studies, he began to work already and publish several chemical engineering studies under the supervision of Prof. Raul Mihail and Prof. Octavian Smigelschi, being particularly attracted by the statistical estimation theory, numerical optimization rules, modelling (bio)chemical process kinetics.

After MSc graduation, he began his career as an in-stage plant engineer (obligatory internship) for 3-years (1979-1982) with several state chemical companies in Bucharest, like Cosmetics Miraj co., "Chimica Dudesti" co. Despite of reduced spare time and tedious work over strict industry shifts, he found time to activate as a teaching assistant at UPBuc., related to the course of "Chemical and biochemical reactors" (BSc, MSc applications in modelling, design, optimization, and control).

In 1981 he started his PhD under the supervision of Prof. Raul Mihail, with the theme „Parameter Estimation of Chemical Process Models [19-22](textbook no.1, chap.6), by approaching his preferred 
subject of modelling kinetics of a large number of catalytic chemical processes related to his parallel job with ICECHIM-IECB, including math modelling and simulation of complex chemical reactors, and publishing original numerical algorithms for kinetic parameter statistical estimation, and process optimization.

\section{Research engineer with ICECHIM (Central Inst. of Chemistry)-IECB (Chem. \& Biochem. Energetics Inst.) Bucharest (Romania)}

In 1982, he joined ICECHIM - Chemical \& Biochemical Energetics Institute Bucharest (IECB), (Bio)Catalysis Group, being in charge with modelling the kinetics of a large number of catalytic processes, and with the technological design of the industrial pilot plant at PWB [15].

Here are to be noticed his studies on kinetic modelling of two novel catalytic processes, that is methanol conversion to olefins MTO, or to gasoline MTG, on zeolite/modified silica catalysts. These kinetic studies have been published by Dr. Maria in top chemical engineering journals [7-11], and became the basis for the design of an industrial pilot plant for MTO/MTG processes at PWB, activities in which he made a key contribution. The chemical plant was put into operation in 1985 (Figure 2) $[6,15]$.

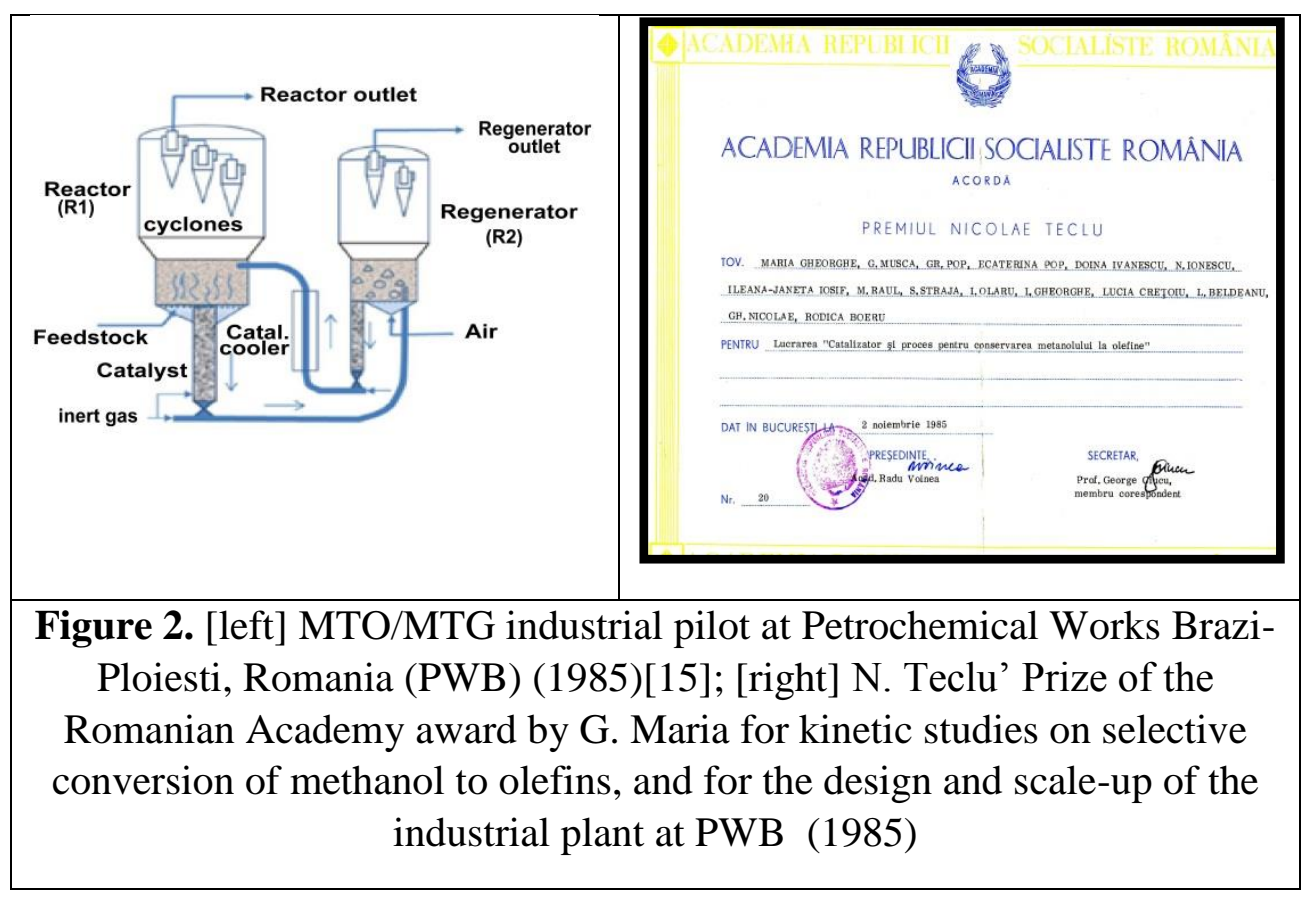

The industrial pilot plant, with characteristics listed in Table 1, and a processing capacity of 400 t/yr., includes two fluidized-bed reactors (FBR): one for conducting the desired reaction (MTO, MTG, etc.), and one for the zeolitic catalyst regeneration. The catalyst has a continuous circulation, by pneumatic transport, between the two reactors [15]. At that time, this demonstrative industrial plant was the first in the world to test the MTO/MTG processes. Only one similar plant of the Mobil Oil comp. USA, was operated in New Zealand, but of a simpler construction, that is a system of 5 fixedbed reactors, successively stopped for the catalyst regeneration, and working under more severe conditions of $350-370^{\circ} \mathrm{C}(\mathrm{MTO}), 400-420 \mathrm{oC}(\mathrm{MTG})$, and 19-27 atm. [36]. Much later, other industrial pilot plants for the MTO process were built-up, by Mobil in Germany (1985), Union Carbide (1986), UOP/Hydro (2005), and China (2015)[36], by adopting the technology of the two inter-connected FBRs, but in different constructive / operating variants. A detailed description of tested catalytic processes and of the MTO/MTG industrial pilot operated at PWB over 1985-1992 was presented in his booklet [15]. 
Table 1. The main characteristics of the industrial pilot plant for the MTO/MTG process from Petrochemical Works Brazi (Ploiesti, Romania, PWBP)[15]

\begin{tabular}{|l|l|}
\hline $\begin{array}{l}\text { Industrial pilot with two catalytic reactors in fluidized- } \\
\text { bed (FBR) }\end{array}$ & $\begin{array}{l}\text { A FBR (reactor), and a FBR regenerator (for catalyst } \\
\text { regeneration). The continuous circulation of the catalyst } \\
\text { between the reactor and the regenerator is accomplished by } \\
\text { pneumatic transport with inert nitrogen. }\end{array}$ \\
\hline FBR Reactor ( vapour phase catalytic reactions) & $0.5 \mathrm{~m}$ in diameter and $7 \mathrm{~m}$ in height \\
\hline $\begin{array}{l}\text { FBR Regenerator (combustion of the coke deposited on } \\
\text { the microscopic catalyst) }\end{array}$ & $0.3 \mathrm{~m}$ in diameter and $7 \mathrm{~m}$ in height \\
\hline LHSV; catalyst avg. size & $0.4-21 / \mathrm{h}$ (for the MTG); $0.06-1 \mathrm{~mm}$ \\
\hline Temperature range & $320-460^{\circ} \mathrm{C}$ (reactor), and $480-560^{\circ} \mathrm{C}$ (regenerator) \\
\hline Pressure & \begin{tabular}{l}
$1-2$ atm. \\
\hline
\end{tabular} \\
Observations & $\begin{array}{l}\text { The pilot is equipped with gas-chromatograph analyzers and process computers connected "on-line" } \\
\text { and "off-line". Approx. 50 process parameters are continuously recorded through appropriate } \\
\text { equipment. A specific software is used for data treatment, including data acquisition, numerical } \\
\text { filtering, statistical calculations, mass and thermal balances, and kinetic evaluations.. }\end{array}$ \\
\hline
\end{tabular}

Following such an exceptional achievement, at both national and international levels, that is i) MTO-MTG process dynamics investigation, ii) the corresponding industrial pilot plant design, building-up, and put into operation at PWB, and iii) testing various catalytic processes at the PWB pilot-plant scale, Dr. Maria was awarded the "N. Teclu" Prize of the Romanian Academy for 1985 (Figure 2). The published MTO/MTG kinetic models became reference models with lots of citations. Beside testing MTO/MTG processes on this industrial pilot plant at PWB, dr. Maria developed and published lot of kinetic studies and pilot tests (1985-1992) for several other catalytic processes conducted on zeolite catalysts, such as [15]: i) selective alkylation of C4 olefins with methanol (OA), ii) Benzene or Ethylbenzene (EB) alkylation with ethene to get higher aromatics, iii) Ethanol conversion to olefins (EtOH), iv) Methanol conversion to BTX (aromatic hydrocarbons). All these studies have been developed within the IECB, (Bio)Catalysis Group, which provided lab-scale experimental data [15].

\begin{tabular}{|c|c|c|c|c|}
\hline \multirow[t]{5}{*}{51.912000} & \multicolumn{4}{|c|}{ 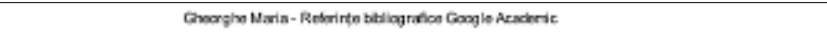 } \\
\hline & \multirow{4}{*}{$\begin{array}{l}\text { Gheorghe Maria } \\
\text { Prolessor, Dept. Chem. \& Biochem. Eng., } \\
\text { Univ. } \\
\text { Politehnica of Bucharest } \\
\text { chemical and biochemical engineering } \\
\text { mathematical (kinetic) modeling estimati... } \\
\text { cell process modelling } \\
\text { risk }\end{array}$} & \multicolumn{3}{|c|}{ CREAȚLVẢ PROPRIUL PROFL. } \\
\hline & & $\begin{array}{l}\text { Reforinte } \\
\text { biofografice }\end{array}$ & & 581 \\
\hline & & hindex & 20 & 12 \\
\hline & & i10-index & 49 & 20 \\
\hline \multicolumn{3}{|l|}{ TITLU } & CITAT DE & ANUL \\
\hline \multicolumn{3}{|c|}{$\begin{array}{l}\text { A review of algorithms and trends in kinetic model identification for } \\
\text { chemical and biochemical systems } \\
\text { G Maria } \\
\text { Chemical and Biochemical Engineering Quarterly } 18 \text { (3). 195-222 }\end{array}$} & 106 & 2004 \\
\hline \multicolumn{3}{|c|}{$\begin{array}{l}\text { Evaluation of multivalent dendrimers based on melamine: kinetics of thiol- } \\
\text { disulide exchange depends on the structure of the dendrimer } \\
\text { W Zhang. SE Tichy, LM Pérez, GC Maria, PA Lindahl, EE Simanek } \\
\text { Joumal of the American Chemical Society } 125 \text { (17) 5086-5094 }\end{array}$} & 72 & 2003 \\
\hline \multicolumn{3}{|c|}{$\begin{array}{l}\text { Modelling and scaleup of the kinetics with deactivation of } \\
\text { methylcyclohexane dehydrogenation for hydrogen energy storage } \\
\text { G Maria, A Marin. C Wyss, S Muller, E Newson } \\
\text { Cherrical onginering scionse } 51 \text { (11), 2991-2896 }\end{array}$} & 56 & 1996 \\
\hline \multicolumn{3}{|c|}{$\begin{array}{l}\text { A Kinetic Model for Methanol Conversion to Hydrocarbons } \\
\text { R Mihai, S Straja, G Meria, G Musca, G Poo } \\
\text { Chamical Enginecring Sciance 38, 1591-1591 }\end{array}$} & 51 & 1983 \\
\hline \multicolumn{3}{|c|}{$\begin{array}{l}\text { An adaptive strategy for solving kinetic model concomitamt estimation- } \\
\text { reduction problems } \\
\text { G Maris } \\
\text { The Canadin Joumal of Chemical Engineering } 67 \text { (5). } 825-832\end{array}$} & 39 & 1989 \\
\hline \multicolumn{3}{|c|}{$\begin{array}{l}\text { Kinetic model for methanol conwersion to olefins } \\
\text { R Mihail, S Straja, G Maria, G Musca, G Pop } \\
\text { Industria \& Engineering Chemistry Process Design and Developenent } 22 \text { (3 ... }\end{array}$} & 38 & 1983 \\
\hline
\end{tabular}

Figure 3. The most cited first 6 papers of prof. Maria in Googleschoolar 


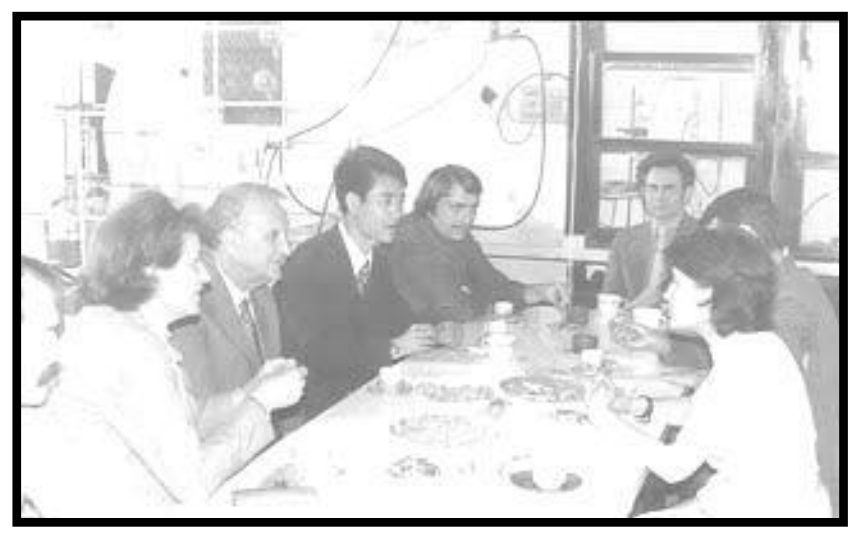

Figure 4. Early activity with UPBuc., as a phd student and asstn. Professor

(from 1980, and then as titular associate professor (from 1990).

In the chemical reactors lab. on 1982 together with (from left) lector Iosif Nagy (now retired),

late prof. C. Balaban, late prof. Raul Mihail, late dr. L.C.Tao (China), myself,

prof. O. Muntean(now retired), dr. S. Straja (now living in USA), and late lector M. Filipescu

\section{Tenure at ETH Zurich (Switzerland, 1992-1997)}

Following the socio-political transformations of Romania after the collapse of communism in 1990, in 1992 Dr. Maria chose to follow an invitation and he came to Switzerland to work as Assistant Professor (Oberassistent Klass 18) with ETH Zürich in the Process System Engineering group of the late Prof. David W.T. Rippin (Technische Chemie Dept.). Here he was involved in teaching activities, by supervising several $\mathrm{PhD} / \mathrm{MSc}$. projects. Besides, he actively participated as a senior investigator to several important research projects of the group, all in the (bio)chemical engineering area (Figure 5).

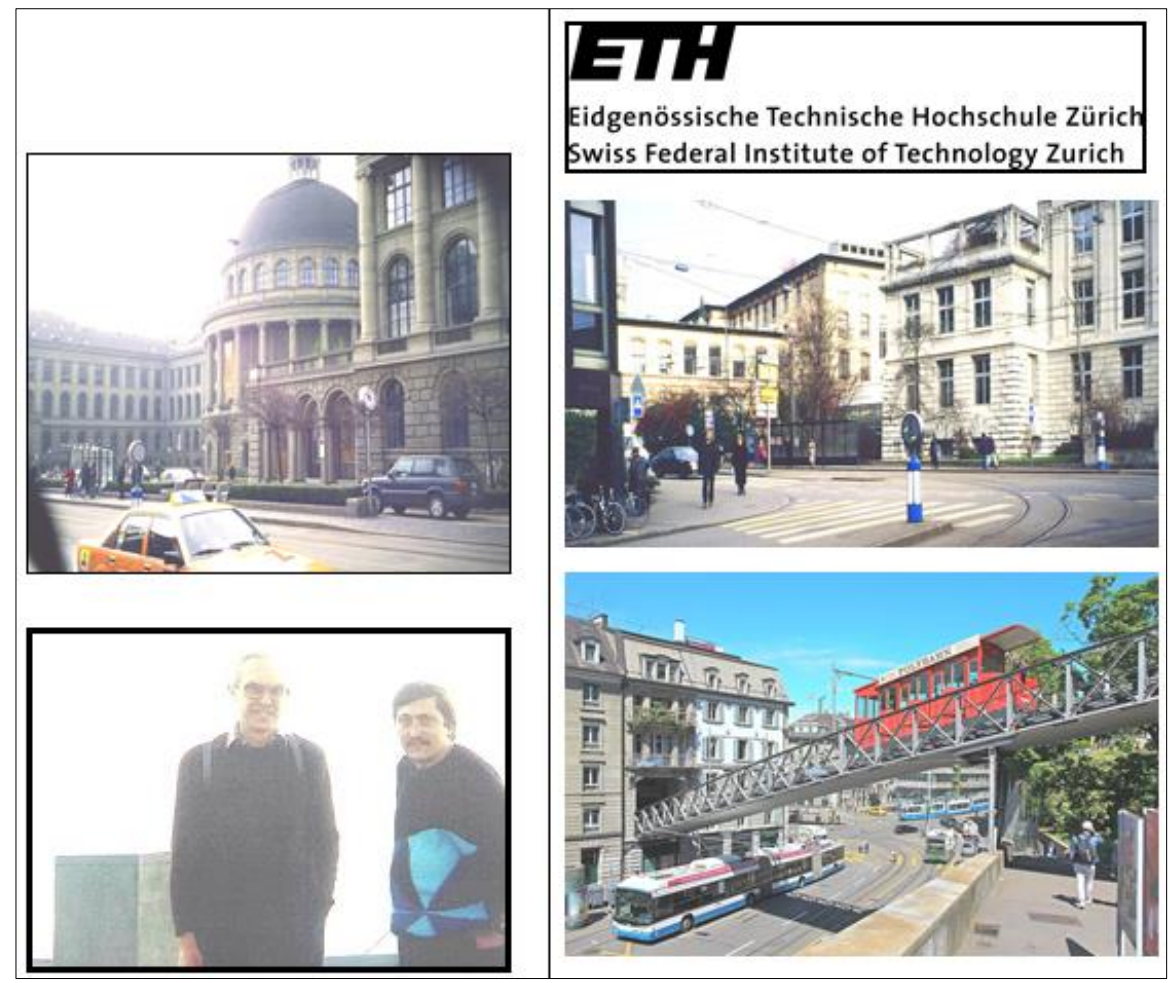

Figure 5. [Up-left]: ETH Rektorat; [Up-Right]: Technische Chemie building on Universitatstrasse (1992-1997). [Down-right] the ETH Polybahn. [Down-left]Together with late Prof. D.W.T. Rippin at ETH Zurich (1993) 
In this regard, it is worth mentioning, he was a key investigator in the project NEFF 505(19921997) "Saisonale Speicherung von Elektrizitat mit Chemisch Gebundenem Wasserstoff", at ETH Zürich, and Paul Scherrer Institut Villigen (PSI, Switzerland). The project was developed and tested at a lab-scale on a catalytic pilot at PSI in cooperation with German DFG and French Vinci co. The project was aiming at transporting chemically stored hydrogen between continents. First, the hydrogen is stored by catalytic hydrogenation of toluene to methylcyclohexane $(\mathrm{MCH})$; then, $\mathrm{MCH}$ is transported by sea to the beneficiary where hydrogenation is released by catalytically dehydrogenation to toluene, which is back returned to the hydrogen source, and the cycle is resumed. Dr. Maria was in charge with developing the kinetic models for the two hydrogenation-dehydrogenation catalytic processes, later used to design and optimise the pilot plant (fixed-bed) of PSI [24].

He was also involved in developing safety analysis of some industrial chemical reactors (that is the catalytic semi-batch reactor used for acetoacetylation of pyrrole with diketene at CIBA-NOVARTIS, Basel). Starting from this experience he later published a lot of papers dedicated to multi-objective optimization of risky chemical reactors by also considering a safety measure expressed in an original probabilistic way $[2,3,35]$. Their notable contributions in this area allowed him to write the first textbook in Romania dedicated to the safety issues in chemical engineering (Textbook no.2, chap.6), and to introduce this course in the Chem. Eng. curricula at UPBuc. (BSc and MSc, Table 2).

At ETH Prof. Maria also developed and published KINEXP, an expert system for the identification and estimation of kinetic models for given (bio)chemical processes, based on known experimental kinetic curves [25-28]. The software uses an own kinetic databank, which includes various template kinetic models, and associated species kinetic curves, imported from solved case studies in literature. KINEXP uses a transfer of information original rule MIP [28], and a combination of direct and indirect methods to solve the NLP, MINLP problems (notations in Table 4), most of them being original ones (MMA, TFA, Table 4)[2, 24-29,35]. Additionally, to help the kinetic model identification process of KINEXP, dr. Maria proposed an original statistical test ["lambda-by-sigma square", linked to target factor analysis TFA , by detecting the redundant parts of the model [29].

He also coordinated a RO(UPBuc)-CH(ETH) a SNSF (Swiss National Science Foundation) Project no. 7IP - 050113 /1997-1998 on „Ecological and Risk Analysis in Chemistry” (having as partner the group of Prof. Konrad Hungerbühler).

\section{Tenure at Univ.Politehnica of Bucharest (U.P.Buc.) Commitment to excellence in Teaching (associate from 1981, titular from 1991)}

During his PhD stage (1981-1987), dr. Maria was a teaching/research assistant with UPBuc. (chemical reaction engineering lab). In 1990 he joined UPBuc. as a full lecturer. With perseverance, conscientiousness, hard working, and a tireless investigator and creative spirit, he promoted all the university ranks until full professor. On 1997 dr. Maria returned from ETH Zurich to Romania (after a stay abroad of ca. 6.5 yrs. 1992-1998), becoming Associate Professor (1997), and then full Professor (1999) with UPBuc, by teaching courses in (bio)chemical reaction engineering, at BSc or MSc level, but also in statistical treatment of (bio)chemical data. He approached classic fields, such as (bio)chemical reactors math (dynamic) modelling, optimization and control, (bio)chemical process kinetic modelling. But he also approached and introduced at UPBuc. modern teaching/research fields, required by the EU curricula, by writing 5 teaching manuals, and textbooks (chap. 6), being the promoter of several courses (Table 2), at BSc., MSc, or PhD level.

Such novel courses, consistent with those developed in EU, derived from his large practical (inter)national experience, being a recognized expert on these topics for various EU (FP6), or national (Biotech) research programs.

Thus, the positive experience acquired when solving international projects on bioinformatics (math modelling of metabolic process dynamics in living cells aiming to design GMO of industrial use) with Texas A\&M university (chap.5), allowed him to write the first 3 text-books in Romania $[13,17,18]$ on 
such a subject, and to introduce a novel course on "Metabolic engineering and bioinformatics", and "biochemical engineering" in the curricula of biochemical engineering at UPBuc. (Table 2). Similarly, starting from the positive experience acquired at ETH when involved in developing safety analysis of some industrial chemical reactors (chap.3), and from a large number of industrial case-studies dealing with optimization of risky chemical reactors, he published many original contributions in this area (chap.7C) which, eventually, allowed him to write the first textbook in Romania on this subject (no. 2, chap.6), with also introducing such a novel course in the Chem. Eng. curricula at UPBuc. (Table 2).

Academic and research interests. Being focused on math modelling and CAPE (computer application in (bio)chemical process engineering), dr. Maria's research interests cover a wide range of areas, including basic fields [(bio)chemical reactors, and reaction engineering], but also novel emergent of frontier fields as mentioned in chap.7 [2,35]

Participation to nternational collaborative projects. His involvement and publications in such research topics are coming from his vivid and very creative spirit, and tireless research in the vast domain of modelling, design, and optimization of (bio)chemical/cell processes. Thus, many of his publications in such frontier fields are coming from his involvement in more than 20 international collaborative projects, by performing multiple research stages at various universities as below mentioned:

- Germany [ BASF Ludwigshafen (1996), TU Erlangen (2000) on „Kinetics Identification and Process Simulation for the Drinking Water Denitrification via a Three-Phase Catalytic Membrane Reactor"; TU Saarbrucken $(1999,2009)$ on „Testing Novel Short-Cut Methods for Kinetic Characterisation of Biochemical Processes”; TU Aachen (2004), TU Hamburg (2009) on: „Dynamic modelling of some genetic regulatory circuits to simulate the bacterial resistance in a polluted environment by using the whole-cell modelling approach"; TU Braunschweig (2006) on „Development of Biotechnological Processes by Integrating Genetic and Engineering Methods"];

- Switzerland ETH-Zurich (1992-1998, various projects, chap.3);

- Portugal [Porto, Coimbra(1999-2000) on „Identification of Optimal Operating Conditions and Risk Limits for Biological Wastewater Treatment Plants"];

- Canada [Kingstown, (1994) on "Statistical data treatment"];

- USA [Princeton(1994), Texas A\&M)(2002-2003) on „Kinetic simulations of minimal living systems”, and „Molecular recognition in dendrimers based on melamine - Kinetics of programmable drug release in human plasma"];

- China [(Tianjin)(2010), on „Simulation and applications of integrated cellular networks ”];

- France [Grenoble (1996), Montpellier (1998) on "Kinetic modelling of (bio)chemical processes"].

Prof Raul Mihail (1920-1985) was the creator of the Romanian school of (bio)chemical reactors, by publishing the first books of "Chemical Reactors" (1971) in the country (and third in the world), and of "Bioreactors" (1988). This school was strengthened and continued by the brilliant textbooks of Prof. Ovidiu Muntean (1983-2003). Prof. Maria was one of their continuers making a bridge over years with the modern school of chemical and biochemical reactors and reaction engineering at UPBuc., by developing and promoting it through projects, published papers[2,35], and textbooks (chap. 6, [2,35]), and through applications in academia and chemical industry, by approaching novel process engineering aspects, such as: advanced kinetic modelling, model-based design of (bio)chemical plants, safety engineering, reactor operation optimization, bioinformatics, bioengineering.

In 1987 G. Maria finalized his PhD studies and got the PhD degree at UPBuc [19-22] (textbooks no.1,3,5, chap.6). In 2008 Dr. Maria received his habilitation to became a PhD supervisor at UPB in the (bio)chemical reaction engineering area, with 7 finalized $\mathrm{PhDs}$, and 3 in progress, with the approached subjects given on [2,35].

In short, as a member of the Dept. of Chemical and Biochemical Engineering of UPBuc. $[2,3,35]$ (Figure 4), Prof. Maria lead PhD, MSc, BSc courses/studies in Chemical and Biochem. reaction eng., leading the group/MSc. in Biochemical engineering (2006-2011)[4,32]. Also, he has laid the foundation of several novel courses (Table 2) introduced in the chemical engineering curricula. He 
participated to a very large number of national (27) and international projects (20) in his research topics (chap.2,5,7).

Table 2. Teach courses, and novel courses introduced by Dr. Maria in the chemical engineers curricula at UPBuc., having as support their published textbooks no. 1-5, and those published in USA (chap.6)

- (Bio)Chemical Reaction Engineering (BSc in Chem. Eng., from 1987)
- Numerical and statistic methods for (bio)chemical data treatment and parameter estimation of
(bio)chemical process kinetic models (BSc, MSc in Chem. Eng., Food Eng.)(newly introduced
from 1997)
- Chemical Process Quantitative Risk Analysis and modelling of accident consequences (BSc,
MSc in Chem. Eng.) (newly introduced from 2006); UPB.11.S.06.O.519; UPB.11.S.10.O.208
- (Bio)Chemical technology/engineering (BSc in Food Eng., from 2015); UPB.11.S.08.O.414
Metabolic Engineering and Bioinformatics (M.Sc. in Food Eng., Biochemical Eng.) (newly
introduced from 2004); UPB.11.S.09.O.0406.(aiming to in-silico design genetic modified micro-
organisms ( $(\underline{\mathbf{G M O}}$ ) of industrial use).

\section{Senior NIH fellow with Texas A\&M Univ. (USA, 2002-2003)}

In 2002, prof. Maria chose to follow an invitation and he came to USA to work as a Senior Scientist with Texas A\&M Univ (TAMU, College Station), Dept. of Chemistry, Biochemistry, and Cell Biology in the framework of two National Institute of Health (NIH) projects of Prof. P. Lindahl, and of Prof. E. Simanek (Figure 6).

Here, at TAMU, prof. Maria was involved as a key investigator in two NIH funded projects of the department, that is: PAL-GM63958 / 2002-2003: „Kinetic simulations of minimal living systems”, and EES-GM64650 / 2002-2003: „Molecular recognition in dendrimers based on melamine - Kinetics of programmable drug release in human plasma". Over short time, he reported multiple contributions in (bio)chemical reaction engineering, and bioinformatics part, by developing kinetic models for essential metabolic processes in living cells, and kinetic models for the controlled drug release in human plasma. Besides, he was also involved in supervising several $\mathrm{PhD} / \mathrm{MSc}$. student projects (Yang Qingwu; Xiang Shi Tan).

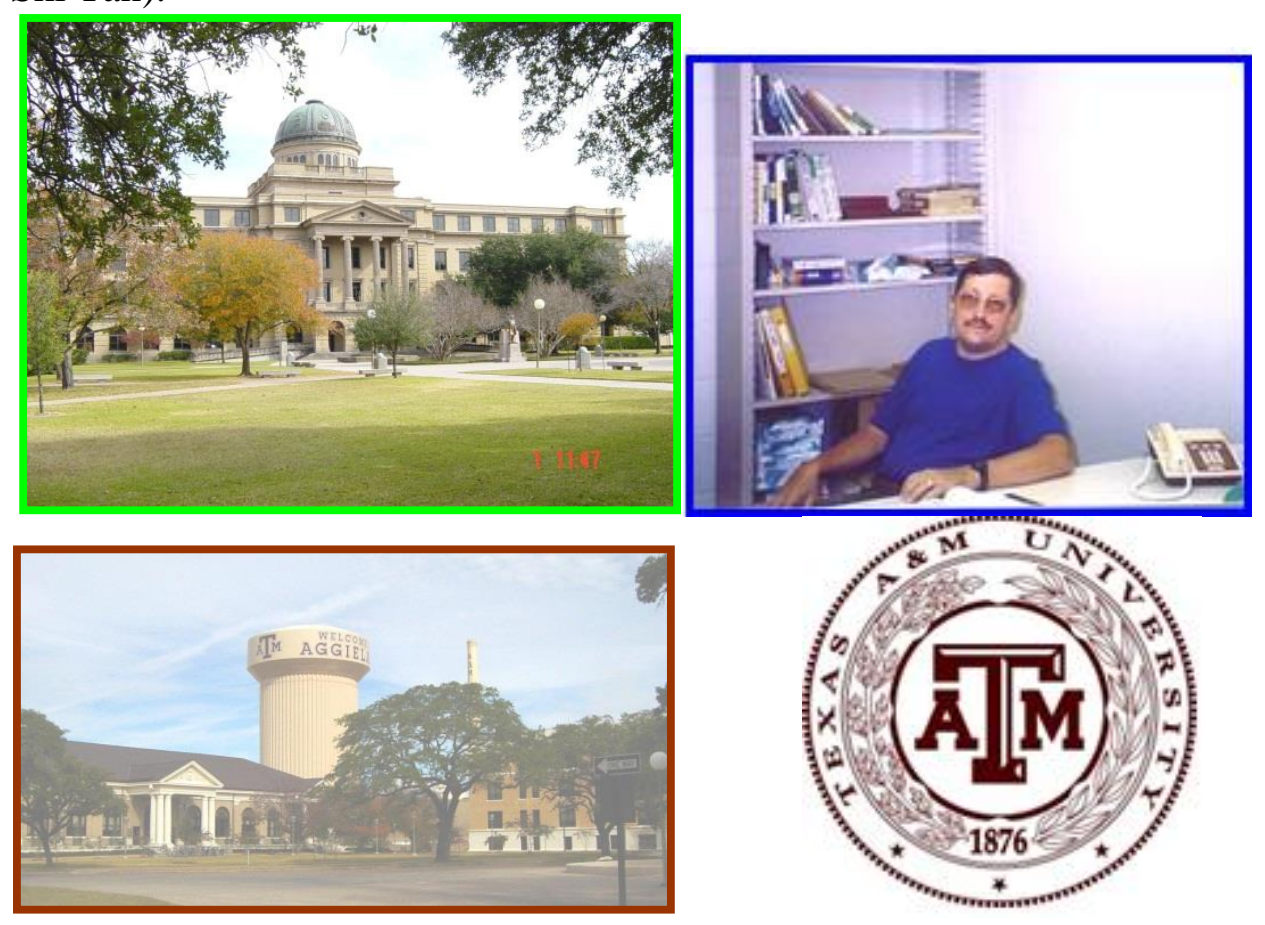




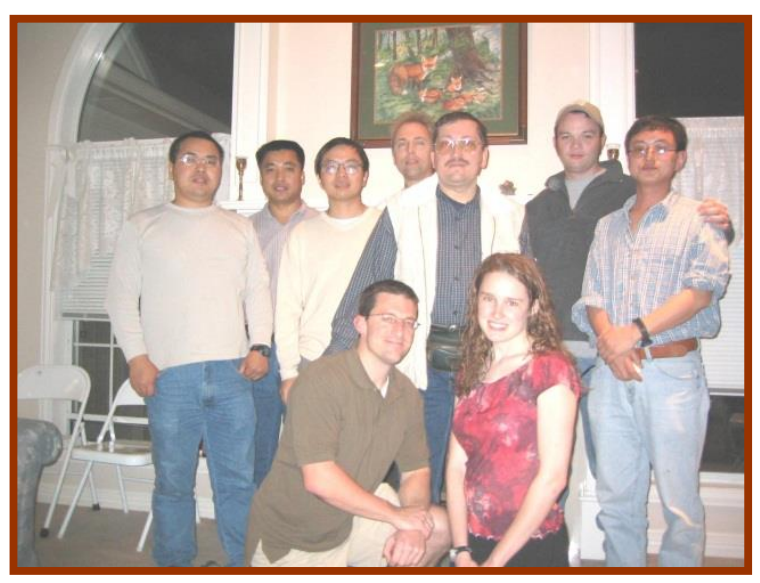

Figure 6. NIH Research activity at Texas A\&M University (College Station, USA) (2002-2003). [Up-left] The faculty of chemistry and cell biology. [Up-right] My working office at TAMU. [Middle] a view from TAMU campus. [Down]: The NIH dedicated group of prof. Lindahl

In the PAL-GM63958 project, their theoretical studies focus on the development of reduced kinetic models for representing the dynamics of individual gene expression regulatory modules (GERM), and of genetic regulatory circuits $(\underline{\mathbf{G R C}})$ in living bacteria of interest. Dr. Maria proposed novel modelling approaches similar to those used in (bio)chemical engineering and nonlinear systems theory, by publishing a lot of contributions (e.g. iron metabolism model in mitochondria[18]). Such dynamic simulators of GRC have proved to be useful for in-silico design of GMO with applications in the biosynthesis industry, medicine, environ. eng., etc. [2,13,17,18]. In the EES-GM64650 grant, based on TAMU experiments, theoretical studies of dr. Maria have focused on the development of extended and reduced kinetic models for representing/designing the chemically controlled drug release from multivalent dendrimeric supports in biological fluids. [33,34].

\section{Textbooks:}

Based on his own research experience with industrial applications over lots of research projects (chap.4), Prof. Maria published $\underline{\mathbf{1 1}}$ highly influential ISBN textbooks (므 in RO, and $\underline{\mathbf{5}}$ in USA) for teaching purpose (Table 3; [35]). The impact of these textbooks has been attributed to the extensive background of Prof. Maria, acquired during the large number of solved case studies in the framework of the large number of national (27) and international (20) projects (chap.4) to which he attended as a key investigator. Such a large work experience, provided him with the context into the connections between the macro- and micro-/nano-(cell-)scale of chemical and biochemical reaction engineering, and the large similitude in the dynamic simulation of metabolic processes in living cells with simulation of the dynamic macroscopic (bio)chemical/biological systems. He also published several ebooks in Bioinformatics in USA [13,17,18].

Table 3. The most relevant published textbooks in RO (with ISBN) of dr. Maria $\hat{A}$ (complete list in $[2,35]$ )

1.Iordache, O., Maria, G., Corbu, S., Modelarea statistică şi estimarea parametrilor proceselor chimice (Statistical
Modelling and Estimation of Chemical Process Models), Rom. Academy Publ., Bucharest, 1991, (300 pages), ISBN
973-27-0195-1.
2.Maria, G., Evaluarea cantitativă a riscului proceselor chimice şi modelarea consecinţelor accidentelor (Chemical
Process Quantitative Risk Analysis and Modelling of Accident Consequences), Printech Publ., Bucharest, 2007
(630 pages), ISBN 978-973-718-667-6.
3.Maria, G., Analiza statistică şi corelarea datelor experimentale (bio)chimice. Repartiţii şi estimatori statistici
(Statistical data analysis and correlations. Distributions and estimators), Printech Publ, Bucharest, 2008 (550 pag.),
ISBN 978-973-718-886-1.


4.Maria, G., Luta, I., Tehnici de modelare cinetică şi de proiectare in-silico a structurilor mezoporoase funcţionalizate la eliberarea controlată de principii biologic active (Kinetic models for the in-silico design of functionalized mesoporous supports for the controlled release of biological active principles), Printech Publ, Bucharest, 2015 (476 pag.), ISBN 978-606-23-0443-0.

5.Maria, G., Crisan, M., Maria, C., Estimarea parametrilor modelelor cinetice ale proceselor (bio)chimice, (Parameter estimation of the (Bio)chemical process kinetic models), Printech Publ., Bucharest, 2016 (528 pag.), ISBN 978-606-23-0633-5.

6.Maria, G., Algoritmi numerici de simplificare a modelelor cinetice ale proceselor chimice şi biochimice (Numerical methods to reduce the kinetic models of (bio)chemical processes), Printech Publ., Bucharest, 2019 (815 pages), ISBN 978-606-23-1010-3. (in Romanian). https://acad.ro/carti2019/carte02-MariaGheorghe

These textbooks are completed by $\underline{\mathbf{6}}$ ISBN book chapters abroad [2,35]. In Romania, the above teaching books published by Prof. Maria have proved to be highly influential, being the first written courses dedicated to the mentioned subjects in Romania, and used in the main universities of RO to complete the instruction of chemical engineering with novel courses (Table 2). The books include theoretical aspects well balanced with solved case studies, accompanied by routines in Matlab, or Excel codes. The mentioned review ebooks published in USA are the first in Romania providing a novel perspective of biochemical engineering in border areas, such as bioinformatics, and systems biology.

\section{Commitment to excellence in Research}

Following their international cooperations (chap.4), and large practical experience, the scientific productivity (publications) of Prof. Maria in these research areas is impressive (chap.7), including many original contributions. Thus, Prof. Maria authored $\underline{\mathbf{1 1}}$ ISBN books (므 in RO, $\underline{\mathbf{5}}$ in USA), $\underline{\mathbf{5}}$ teaching books (RO), $\underline{\mathbf{6}}$ ISBN book chapters, more than $\underline{\mathbf{1 4 9}}$ papers[2,35] in peer reviewed ISI international journals and univ. journals (most of them as principal author), and $\underline{\mathbf{8 0}}$ in intl. conference proceedings[2], with more than $\underline{\mathbf{1 4 0 0}}$ citations (h-index $\underline{\mathbf{2 0}}$, i10 index $\underline{\mathbf{4 9}} \underline{\mathrm{g}}$ Googleschoolar). According to the Romanian ranking system(MEdC-OMs-2011), he reported high scores. The most cited first 6 papers (Googleschoolar) of prof. Maria are given in Figure 3. These publications include many original contributions in the following areas:

- (Bio)Chemical reaction engineering,

- CAPE (computer application in process engineering)

- Computational biochemistry, Bioinformatics,

- chemical, biochemical, and biological reactors optimization

- modelling the kinetics of chemical, biochemical (enzymatic) processes, including metabolic processes (genetic regulatory circuits, central carbon metabolism)

- chemical, biochemical, and biological reactors (design, optimization, control)

- (Bio)Process Systems Engineering

Among their significant contributions are to mention the following:

7A. Development of novel and complex kinetic models. Prof. Maria developed more than 40 complex kinetic models for various chemical catalytic, enzymatic, cell metabolic, or drug release processes. These models have been validated at lab, pilot or industrial scale. Among them are to be mentioned the followings [2,3]: MTO, BTX, MTG, EB, EtOH, OA (chap.2), enzymatic oxidation of $\mathrm{D}$-glucose to keto-D-glucose( $\mathrm{kDG}), \mathrm{kDG}$ reduction to fructose in the presence of aldose reductase and NADPH; enzymatic hydrogenation of fructose to mannitol with the in-situ continuous enzymatic regeneration of the NADH cofactor by the expense of formate enzymatic decomposition; oscillating glycolysis in bacteria; interference of the oscillating glycolysis with the oscillating tryptophan synthesis in the E. coli cells, etc.

7B. Modelling dynamics of metabolic processes in the living cells. Particular attention has been paid to modelling dynamics of metabolic processes in the living cells, by introducing novel modelling Rev. Chim., 71 (4), 2020, 1-18 
concepts and rules translated from (bio)chemical engineering principles and nonlinear systems theory. Lot of applications have been developed on In-silico design of genetic modified micro-organisms (GMO)(Systems Biology and Bioinformatics), reviewed in their ebooks published in USA $[13,17,18]$.

7C. Contributions in the risk assessment and multi-objective optimization of risky chemical reactors (RCR). He developed an optimization methodology of $\underline{\mathbf{R C R}}$ (process/reactor model-based predictive control MPC) by combining multi-objective goals, with including economic objectives, but also safety requirements (in a probabilistic/stochastic form)[2-3]. Among the novel algorithms are to be mention: i) evaluate the quasi-stable QFS operating conditions (,quick onset, fair conversion and smooth temperature profile") of $\underline{\mathbf{R C R}}$ based on a generalized sensitivity criterion, corresponding to a super-critical or severe operation; ii) novel algorithms to evaluate risky operating conditions of $\underline{\mathbf{R C R}}$, by modifying the rules of Zaldivar et al. (2003) (based on eigenvalues of the math model Jacobian), of Strozzi-Zaldivar (1994), or Hedges \& Rabitz (1985) (based on Lyapunov numbers derived from the Green matrix eigenvalues); iii) Proposal of a probabilistic index to evaluate the runaway probability of a $\underline{\mathbf{R C R}}$ in the presence of multiple sources of uncertainty; iv) postulate conditions to the occurrence of accidents with Domino effect in surrounding risky chemical plants [2,3].

7D. An industrial outstanding realization of high impact. On 1980-1985, while working with ICECHIM-IECB, dr. G. Maria elaborate kinetic models for the MTO/MTG catalytic processes. Due to such models, he was the key engineer in-charge with the design of an industrial pilot-plant at PWBP for the MTO/MTG processes (chap.2). This industrial pilot was also used to test several catalytic processes, such as (chap.2): MTO,MTG,EB,OA,ETOH,BTX. For such an achievement, dr. G. Maria received the "Nicolae Teclu" Prize of the Romanian Academy on 1985. At that time this plant was the first in the world to test MTO/MTG processes (see details in his Ebook [15]).

7E. Contributions to the basic numerical calculus and statistical algorithms [19-22]. The most important are shortly described in Table 4. See also their textbooks no.1, 3, and 5 of chap.6.

Table 4. The most important numerical algorithms developed and published by prof. Maria

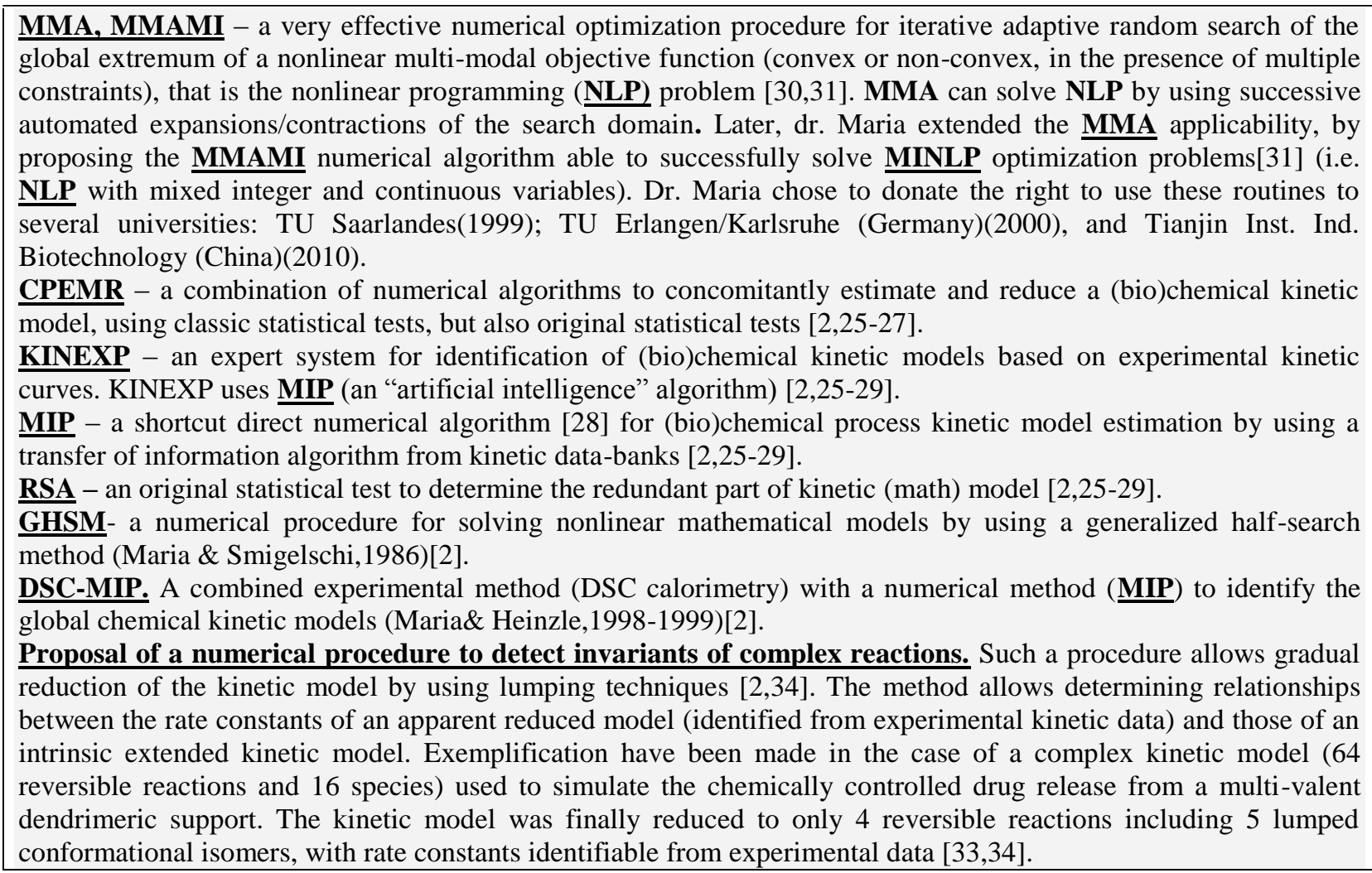


7F. A combined experimental method (DSC calorimetry ) with a numerical method (original shortcut MIP)[2]. The procedure identify the global chemical kinetic models in the early safety assessment of chemical processes.

7G. Numerical procedure to detect complex reaction invariants for the gradual reduction of kinetic models by using lumping techniques. The algorithm allows determining the relationships between the rate constants of an apparent reduced model (identified from experimental kinetic data) and those of the intrinsic extended kinetic model. Exemplification and tests have been made in the case of a complex kinetic model (64 reversible reactions and 16 species) used to simulate the chemical controlled drug release from a multi-valent dendrimeric support based on melamine. The kinetic model was finally reduced to only 4 reversible reactions including 5 lumped conformational isomers, with rate constants perfectly identificabile from experimental data [33]. Besides, the method detect the linear relationships between the rate constants of the extended and reduced kinetic models [34].

7H. Contributions in Bioinformatics, Systems Biology, and Computational Biology are summarized in their review textbooks $[13,15,17,18]$. In short, their contributions concern novel concepts of modular modelling of the dynamics of complex metabolic processes in living cells [ belonging to the central carbon metabolism ( $\underline{\mathbf{C C M}}$ ), genetic regulatory circuits (GRC) ], by introducing novel modelling concepts and rules translated from (bio)chemical engineering principles, and nonlinear systems theory with applications in Systems Biology and Synthetic Biology for the insilico design of GMO. Among these are to be mentioned the following. See $[13,17,18]$ for case studies:

7Ha) Proposal of a large number of dynamic models (on a deterministic basis) to simulate various metabolic processes in living cells, related to $\underline{\mathbf{C C M}}$, individual gene expression (GERM), or chains $\underline{\text { GRC }}$ of a modular construction, all being used to design GMO (applications in [18]).

$\underline{7 \mathbf{H b})} \mathrm{As}$ a major contribution in the theoretical / math modelling of the metabolism in living cells (single cell analysis), it is proposal of a novel modelling concept / framework to derive cell kinetic models, in a holistic approach, that is the so-called "variable-volume-whole-cell" VVWC modelling framework [13], useful to build-up dynamic models for simulating cellular GRC for protein synthesis, glycolysis, and other essential CCM processes [17-18]. While the past and current cell dynamic models ensure some holistic cell properties (e.g. homeostasis, self-regulation of GERM, perturbation treatment, etc.), by imposing a lot of constraints (such as "the total enzyme activity", and "total enzyme concentration", etc.), but ignoring the cell volume increase, dr. Maria promoted inclusion of thermodynamic isotonicity constraints, and, proves step-by-step in a mathematical way, that, in a VVWC model formulation, such constraints ensure cellular intrinsic properties in a natural way (and not derived from artificial hypotheses). The advantages of using VVWC modelling framework, and of such novel modelling concepts, and rules translated from (bio)chemical engineering principles and nonlinear systems theory are explained, proved, and exemplified in [13,17,18]. Under the novel VVWC framework and concepts (modular, holistic approach, lumped representation), he developed a significant number of math models. Among them, it is to mention the developed library of GERM modular models, characterized by using quantitative measures introduced by dr. Maria. $\underline{\text { GERM }}$ modules can be used to $\underline{\text { in-silico }}$ build-up complex modular GRCs and $\underline{\text { GMO }}$ of desired characteristics $[13,17,18]$, with lot of applications in industry, medicine, etc.

7Hc). Development of a significant number of kinetic cell models under the novel VVWC framework. These models allow to characterize the dynamics of various metabolic cell processes,

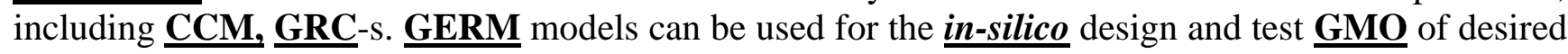
characteristics leading to bioreactor optimisation (details and examples in $[13,17,18]$ ).

\section{K. Development of kinetic models to simulate the drug release in biological fluids.}

7Ka) Novel kinetic models to simulate the controlled drug release from (non-)functionalized porous supports in biological fluids with chemical and/or diffusional control. Examples include the release of various test drugs (irinotecan, amikacin, anti-TBC, cephalosporines, etc.) from (Al-)MCM- 
41 (non-)functionalized silica supports in intestinal fluids, or controlled released of drugs from multivalent dendrimeric supports based on melamine in human plasma (book no.4 in chap.6).

7Kb). in-silico design of optimized drug-linker-support systems. Develop deterministic complex kinetic models for drug release that include enough parameters, related to support characteristics, drug parameters, reticulation agent properties, and biological receptor fluid to allow in-silico design of optimized drug release systems, including multi-linker systems.

7Kc). In-silico modulate chemically controlled drug release in human plasma. The case study refers to the release of a drug linked by disulphide bonds on a tetra-valent dendrimeric support based on melamine (chap.7G)[33,34].

7L. Modelling, and optimization of chemical, enzymatic reactors, and bioreactor operation in various constructive and operating alternatives.

In 2012, dr. Maria proposed a systematic computing methodology, based on a modular simulation platform [2], seeking for the selection of the most suitable reactor for a given enzymatic process of known kinetic model. The numerical procedure compares the performances of the main types of enzymatic reactors. Eventually, the simulation platform is able to calculate the optimal operation policy of the chosen enzymatic reactor. This procedure can also help in determining the level of enzyme stability that makes an operating alternative to be economically preferred.

The simulation-optimization platform included models of the common enzymatic reactors, that is: batch reactor (BR) with initial addition of enzyme and substrate(s); BR with intermittent addition of enzyme/ substrate(s) following a certain addition policy (BRP); semi-batch reactor with a continuous constant/variable feed flow rate of the enzyme/substrate(s) solution (SBR); mechanically agitated continuous reactor with immobilized enzyme on a suspended porous support (MACR); fixed-bed continuous reactor with immobilized enzyme on porous support packed in columns (FXBR). Exemplification has been made for several case studies [2,3,18]: i) MACR for D-glucose oxidation to keto-glucose in the presence of pyranose oxidase and catalase by means of the Pareto-optimal front numerical technique (Maria \& Crisan, 2015,2017); ii) MACR for fructose reduction to mannitol in the presence of $\mathrm{MDH}$ (mannitol dehydrogenase) and $\mathrm{NADH}$, with intermittent addition of MDH enzyme. The process co-factor NADH is continuously regenerated in-situ by the expense of formate decomposition in the presence of FDH (Formate dehydrogenase) (Maria \& Crisan, 2017); iii) SBR multi-enzymatic reactor for inuline hydrolysis (Maria, 2012), or for starch hydrolysis (Maria, 2012); iv) MACR bioreactor for mercury ions removal from wastewaters by using bacterial cultures immobilized on porous alginate supports (Scoban \& Maria, 2016,2017); v) MACR bioreactor for mercury ions removal from wastewaters by using bacterial immobilised cultures of Pseudomonas putida cells (Maria \& Luţă, 2013)[18]; vi) SBR bioreactor for tryptophan production by using E. coli cultures (Maria et al.,2018)[18]; vii) SBR to maximize production of monoclonal antibodies by using a hybridoma cell culture [18].

\section{Service to Chemical \& Biochemical Reaction Engineering:}

Prof. Maria has been active in professional organizations and supportive of the chemical and biochemical reaction engineering research, and PSE community. Thus, Dr Maria has undergone an intense activity in the CAPE (Computer Application in Chemical Engineering), that is a dedicated section of the EFCE (European Federation of Chemical Engineering), being the Romanian representative in 2005 (Davos), and 2011 (Berlin). Prof. Maria was co-chairman of ESCAPE-17 conf. Bucharest (2007). He published a lot of papers in Computers \& Chem. Eng. (more than 15). He participated with consistent contributions to various ESCAPE Conf, as following: 1992 Toulouse (France); 1995 Bled (Slovenia)(plenary lecture); 1996 Rhodes (Greece); 1999 Budapest (Hungary); 2000 Florence (Italy); 2007 Bucharest (Romania). Prof. Maria presented more than 31 invited Lectures at various Universities in EU, CAN, USA, and China. Among them: Princeton Univ. 1994, Texas 
A\&M University 2002, EPFL Lausanne 1992-1997, Queen's Univ. Kingston Canada 1994, BASF Ludwigshafen 1996.

He is a reviewer for many (bio)chemical engineering journals (25). He also has an intense editorial activity, being member in the scientific/ editorial board of the followings scientific journals: I) Chem. \& Biochem. Eng. Q. (Zagreb); ii) Rev. Chimie (Bucharest); iii) Scientific Bull. UPBuc.; iv) Bulletin Romanian Chemical Eng. Soc.; v) ECOTERRA Jl. Environ. Res. \& Protection (Cluj, Romania).

Prof. Maria co-chaired or was member of org. Committees of 16 international conferences. Among them: 5th Int. Conf. Computational Bioeng., 11-13 Sept. 2013, Leuven, Belgium; 15th Int. Conf. Physical Chemistry, 11-13 Sept. 2013, Bucharest; 13th Conf. Academic Days, Timisoara (RO), June 13-14, 2013; ELSEDIMA 10 $0^{\text {th }}, 11^{\text {th }}, 12^{\text {th }}$ Int. Conf. On Safety Engineering, 18-19 Sept. 2014; 26-28 May 2016, 17-19 May 2018, Cluj-Napoca (RO), etc.

He presented a large number of plenary/key lectures (more than 15) in national and international conferences. Among them: $5^{\text {th }}$ European CAPE Symp., June 11-14, 1995, Bled (Slovenia); 20th Croatian Conf. of Chemists \& Chem. Eng., Feb. 2007, Zagreb (HR); 12th Conf. Academic Days, Timisoara (RO), 26-27 May 2011; 15th Int. Conf. Physical Chemistry, 11-13 Sept. 2013, Bucharest; Int. Conf. Chemistry and Chem. Eng. RICCCE-18, Sinaia (RO), 4-8 Sept. 2013; National symposium "Environment \& Progress", Univ. Babes-Bolyai Cluj (RO), 25 Oct. 2013; $10^{\text {th }}$ ELSEDIMA Int. Conf. On Safety Engineering, 18-19 Sept. 2014, Cluj (RO); Symp. SICHEM-2016 (8 Sept. 2016), SICHEM2018 (7 Sept.2018) at Univ. Politehnica Bucharest, etc.

He was very supportive for the chemical and biochemical engineering teaching, with supervising /coordinating more than 50 BSc licence projects, more than $18 \mathrm{MSc}$-dissertations (1980-2019), and 10 $\mathrm{PhD}$ students in chemical and biochemical reaction engineering at UPBuc. (2008-2019). His involvement and publications in a large area of research topics are coming from his vivid and very creative spirit, and tireless search in the vast domain of modelling, design, and optimization of (bio)chemical processes (chap.7). Thus, many of his publications are coming from his participation over the past 25 years to more than 15 intl. projects, making numerous research stages abroad (chap.4).

Being a strong personality, marked by dedication, and initiative, Prof. Maria was actively involved in educational and research activities in Romania, being part to $\mathrm{PhD}$ analysis committees, and participating to chemical eng. conferences in the country universities (Iasi, Timisoara, Cluj). Thus, he carried out a meritorious activity for the benefit of the academic community. Besides those above mentioned, are to be remembered:

- member of Professorial Councils of the Faculty of Applied Chemistry of UPBuc. (2012-2014);

- Assistant Professor with ETH Zurich (Technische Chemie Dept. 1992-1997);

- fellow of NIH USA at Texas A\&M Univ., Dept. of Chemistry and Cell Biology (College Station USA)(2002-2003);

- member of Romanian Council for Attestation of University Titles, Diplomas \& Certificates CNATCDU (2010-2012);

member of: RO Soc. Chem. Eng.; RO Soc. Chemistry; RO Soc. Bioeng. \& Biotechnol., DAAD Alumni Fellow Assoc. (Germany), RO Soc. Science and Environ. Eng. (Romania);

He is a member of EFCE (European Federation of Chemical Eng.)- national representative 1995,2011 .

\section{Academic accomplishments:}

With supervising more than $50 \mathrm{BSc}$ licence projects, more than $18 \mathrm{MSc}$-dissertations, and $10 \mathrm{PhD}$ students (Figure 7) in chemical and biochemical engineering at UPBuc. (1980-2019), and with an impressive scientific production of over $\underline{\mathbf{2 3 0}}$ papers in ISI journals and intl. Conferences, $\underline{\mathbf{1 1}}$ ISBN books (RO,USA, 6 chapters), $\underline{\mathbf{5}}$ teaching books (UPBuc., RO) [2-4,35], with one industrial plant design at PWBP (1985), and several pilot plants design and put into operation in Romania (at IECB), or Switzerland (at Paul Scherer Inst., NEFF project (chap.3), and with optimized SBR reactors under 
safety requirements (CIBA-Novartis, Basel, 1994-1996), Prof. Maria's publications have a considerable impact on the science and practice of (Bio-)Chemical Reaction Engineering in Romania and world-wide. He is also very supportive of the chemical and biochemical eng. curricula at UPBuc.(RO), by introducing novel courses (Table 2), with publication of dedicated teaching books (chap.6). In recognition to his service to academic community, he received several honours and awards (Table 5).

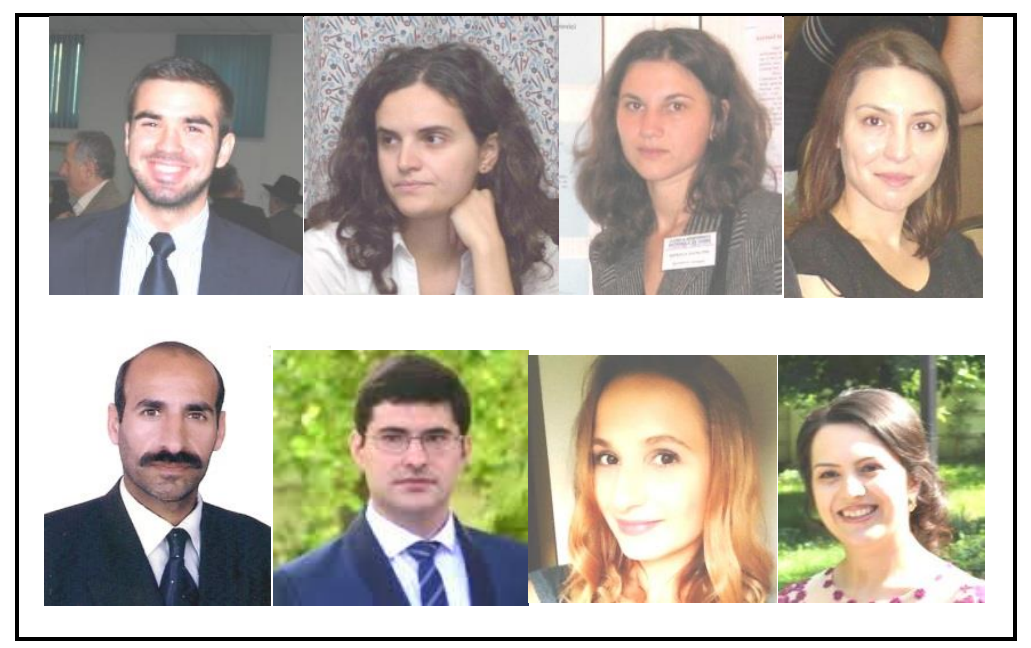

Figure 7. Some PhD-s in chemical and biochemical engineering supervised and trained by prof. G. Maria (2008-2020). From left to right: 2011, Dragos Nicolae STEFAN (VEOLIA Water Techn. Co., Bucharest); 2013, Anca DAN (VTU Engineering s.a. Bucharest); 2013, Manuela Diana BUBOI (married Ene)(Biotehnos s.a. Otopeni); 2014, Ionela LUTA (married TULIGA) (Siemens s.a. Bucharest); 2017, Hasan Hadi Salman KHWAYYIR (Najaf Technical College, Iraq); 2018, Constantin MUSCALU (Siemens s.a. Bucharest); 2019, CRISAN Mara (Siemens s.a. Bucharest) ; 2020, Marina MIHALACHI (married MUSCALU)(Petrodesign Bucharest)

Table 5. Some honours and awards received by prof. Maria

- 'N. Teclu' Prize of the Romanian Academy for kinetic studies on selective conversion of methanol to olefins, and for the design and scale-up of the industrial plant at Petrochemical Works Brazi (1985)(Fig.2);

- Diploma of excellence in research of the Romanian Federation of Biomedical Engineering, 2006[2];

- included in "Who's Who in the World in Science \& Technology" (1996 - in present);

- the gold medal obtained at the Chemistry Olympics for highschools on 1974 (11 participant countries, among which Russia, Germany, Austria, Sweden, Czech Republic, etc.)[23a-b]

- EU Scientific Expert for EC-FP6 Programme - NEST Group (Safety engineering, and Bioengineering), 20032005.

- Swiss National Science Foundation Scientific Expert (Switzerland), 2005-2006.

- Scientific Expert for the Bioeng. RO Res. Program "Biotech", and those of Republic of Croatia, 2006.

- member in the Chemistry/Chemical Eng. Committee of the Romanian Council for Attestation of University Titles, Diplomas \& Certificates CNATCDU (2011-2012).

- 13 awards for the best published papers granted by the Romanian Res. Agency UEFISCDI (2010-2019).

- correspondent member of the Romanian Academy (from 2019, unanimously by votes).

The total devotion to school of Prof. Maria, even at the cost of his health (a severe AVC in 2014), his strong sense of responsibility, self-exigency, team spirit and involvement, brought to Prof. Maria respect and recognition from the colleagues from the Dept. of Chem. and Biochem. Eng. of UPBuc., being appreciated as a balancing factor, but also as a dynamic element in the perpetual renewal of the Department and its adaptation to the requirements of a modern European education and performance.

In any type of activity with students, Prof. Maria managed to mobilize his co-workers to participate in the research topics of great novelty at national and European level, transmitting to them the passion Rev. Chim., 71 (4), 2020, 1-18 
for science, seriousness and education of the "well done job", the joy to participate through continuous self-improvement and getting results published in top international journals.

For us, it was a privilege to collaborate with Prof. Maria, on several publications. Thus, we had the occasion to discover that behind the outstanding scientist there is an encyclopaedic personality. Thanks to him, we got involved in the fascinating area of kinetic modelling of complex enzymatic, and metabolic processes in living cells, but also in the optimization of risky chemical reactors, which are some of his major and well-recognized research areas.

In particular for me (Mara Crisan), it was a privilege to work with Prof. Maria, even for a short period of time, being one of his PhD students. Thanks to him, I got involved in the fascinating area of modelling the of complex multi-enzymatic systems, one of his worldwide recognized research topics.

For his upcoming 65th birthday on October 2020, his colleagues and co-workers, his many friends, former students and all those who had and have the honour to work with him send their wishes for many happy and fruitful years, and a quick recovery of his health. Finally, we want to wish to Prof. Maria good health, fruitful years of scientific activity, by keeping alive the same intense scientific spirit for the benefit of the new generations of chemical engineers.

\section{References}

1. ENE, M.D., Bulletin of Romanian Chemical Engineering Society, 3 (2), 2016, p. 88-93.

2. MARIA, G., personal web-page. https://sites.google.com/site/gheorghemariasite/home

3. MARIA, G., cv at UPB web-page http://www.chimie.upb.ro/departamente/inginerie-chimica-sibiochimica

4.UPB-chem.eng.web-page,http://www.chimie.upb.ro/departamente/inginerie-chimica-si biochimica/cercetare

5. PRABOOK, G. Maria, personal web-page, https://prabook.com/web/gheorghe.maria/413874

6. TSAKIRIS, C., MARIA, G., et al., In: Dynamics and Control of Chemical Reactors, Distilation Columns and Batch Processes, J.G. BALCHEN (Ed.), Pergamon Press, Oxford, 1993, p. 105-109.

7. MiHAil, R., STRAJA, S., MARIA, G., MUSCA, G., POP, G., Ind. Eng. Chem. Proc. Des. Develop. 22, 1983, p. 532-538.

8. MIHAIL, R., STRAJA, S., MARIA, G., MUSCA, G., POP, G., Chem. Eng. Sci. 38, 1983, p. 15811591.

9. POP, G., BOERU, R., MUNTEAN, O., MARIA, G., in: Proc. AIChE'90 Meeting, ALBRIGHT, L. et al., (eds.), Marcel Dekker, New York, 1992, p. 453-463.

10. POP, G., MUSCA, G., IVANESCU, D., POP, E., MARIA, G., CHIRILA, E., in: Proc. AIChE'90 Meeting, ALBRIGHT, L. et al., (eds.), Marcel Dekker, New York, 1992, p. 443-453.

11. MARIA, G., POP, G., MUSCA, G., BOERU, R., In: New Frontiers in Catalysis, L. GUCZI, F. SOLYMOSI, P. TETENYI (Eds.), Elsevier, Amsterdam, 1993, p. 1665-1668. http://www.gbv.de/dms /ilmenau/toc/124410103.PDF

12. SECELEANU, E., Eminescu Publ., Bucuresti, 1982, p. 126-130.

13. MARIA, G., A review of some novel concepts applied to modular modelling of genetic regulatory circuits, Juniper publ., Newbury Park, California, (USA) 2017, ISBN 978-1-946628-03-9. https://juniperpublishers.com/ebook-info.php

14. MARIA, G., Chemical \& Biochemical Engineering Quarterly, 28(4), 2014, p. 509-529.

15. MARIA, G., From residual biomass and inferior quality coal to the synthesis of methanol and then to hydrocarbons and gasoline - a Romanian project of high success , Juniper publ., California (USA), 2018, ISBN 978-1-946628-16-9, https://juniperpublishers.com/ebook-info.php

16. MARIA, G., short cv, 2015, http://www.chimie.upb.ro/departamente/inginerie-chimica-sibiochimica/personal/maria-gheorghe 
17. MARIA, G., Deterministic modelling approach of metabolic processes in living cells - a still powerful tool for representing the metabolic process dynamics, Juniper publ., California (USA), 2017, ISBN 978-1-946628-07-7.

18. MARIA, In-silico design of Genetic Modified Micro-organisms (GMO) of industrial use by using Systems Biology and (Bio)Chemical Engineering tools, Juniper publ., California (USA) 2018, ISBN 978-1-946628-12-1.

19. MARIA, G., Rev. Chim., 38,1987, 705-712.

20. MARIA, G., Rev. Chim, 38, 1987, 798-806.

21. MARIA, G Rev. Chim, 38, 1987, 896-902.

22. MARIA, G., Rev. Chim 39, 1988, 45-49.

23a. WIKIPEDIA, A short history of the international chemistry Olympiad. See web-page=

https://en.wikipedia.org/wiki/International_Chemistry_Olympiad\#cite_note-history-1

23b. IChO, 2007, A short history of the international chemistry Olympiad, See web-page= http://www.icho39.chem.msu.ru/html/english/IChO/History.htm

24. MARIA, G., MARIN, A., WYSS, C., MÜLLER, S., NEWSON, E., Chem. Eng. Science 51, 1996, p. 2891-2896.

25. MARIA, G., RIPPIN, D.W.T., Comput. Chem. Eng. 19, 1995, p. S709-S714.

26. MARIA, G., RIPPIN, D.W.T., Comput. Chem. Eng. 20, 1996, p. S587-S592.

27. MARIA, G., Computers \& Chemical Engineering 17, 1993, p. S435-S440.

28. MARIA, G., RIPPIN, D.W.T., Comput.Chem. Eng. 21, 1997, p. 1169-1190.

29. MARIA, G., RIPPIN, D.W.T., Chem. Eng. Science 48, 1993, p. 3855-3864.

30. MIHAIL, R., MARIA, G., Comput. Chem. Eng. 10, 1986, p. 539-544.

31. MARIA, G., In: Modelling, Identification,Control, M.H. HAMZA (Ed.), IASTED/ACTA Press, Anaheim (CA), 2003, p. 112-118.

32.MARIA, G., In: programe de masterat 2009 -UPBuc., http://www.studentie.ro/postuniversitar/ masterat-arhiva-i60/masterat-stiri-arhiva-c415/programe-de-masterat-2009---universitatea-politehnicabucuresti-id53375

33. ZHANG, W., TICHY, S.E., PEREZ, L.M., MARIA, G., LINDAHL, P.A., SIMANEK, E.E., J. ACS 125(17), 2003, p. 5086-5094.

34. MARIA, G., Chemical Engineering Science 60, 2005, p. 1709-1723.

35.GIJIU, C.L., DINCULESCU, D., CRISAN, M., MARIA, G., Anniversary Professor dr.ing. Gheorghe MARIA at 65 years old - teacher and scientist, Juniper publ. Inc., Simi Valley, California 93063 (USA) ISBN: 978-1-946628-29-9, 2019

36. KEIL, F.J., Methanol-to-hydrocarbons: Process technology, Microporous and Mesoporous Journal, 29, 1999, p. 49-66.

$\overline{\text { Manuscript received: } 24.06 .2019}$ 